\title{
PERANCANGAN PERMAINAN GELEMBUNG HURUF (TOKOH WAYANG) BERBASIS SISTEM OPERASI IOS MENGGUNAKAN GAMESALAD
}

\author{
Adhitama Ksatriya Nugraha $^{1)}$, Kodrat Iman Satoto ${ }^{2)}$, Rinta Kridalukmana ${ }^{2)}$ \\ Program Studi Sistem Komputer, Fakultas Teknik, Universitas Diponegoro, \\ Jln. Prof. Sudharto, Tembalang, Semarang, Indonesia \\ email : adhitama_kn@icloud.com
}

\begin{abstract}
Currently, the globalization and modernization of the country make us forget the traditional culture. Not surprisingly, more people are not familiar with puppet, let alone moved to preserve it. Therefore, in this era get involved use of mobile devices such as smartphones as the most efficient tool as interactive learning media. Now, the use of smart mobile devices are no longer limited by age, therefore developers will try to exploit this as a media that can be used for interactive learning.

Puppets as one of traditional Indonesian art is very typical of Indonesia. Aside from the form or shape, it can be seen also particularities of the story and the character of each puppet characters. Games that are culturally especially puppet is still rare, especially for mobile devices based on its iOS operating system. Thus the authors tried to make a game design that aims to increase knowledge about the names of the puppet characters.

Game development tool use to make this game is GameSalad, with object -oriented programming concepts. GameSalad is one of game development tools that game developers can use to facilitate the making of the game for mobile devices based on the iOS operating system. The design phase begins with analysis requirement and system design. Implementation stage is done by building and developing the game in accordance with the draft that has been made, the implementation of the program. The testing phase is done with a black-box method.

The results show that this game can run well on mobile devices with the iOS operating system. The buttons and functions on the game also can function properly and in accordance with their respective functionality. Based on the assessment provided by a sample of users, the game "Gelembung Huruf (Tokoh Wayang)" is considered attractive, easy to understand and play, able to gain knowledge about the names of the puppet characters, raises curiosity, as well as look good game, so the user's attention to play this game again.
\end{abstract}

Keywords : Bubble Letters, Find the letter, GameSalad, iOS, Puppet

\section{PENDAHULUAN \\ 1.1 Latar Belakang}

Wayang sebagai salah satu alat seni tradisional yang sangat khas bagi Indonesia. Walaupun di dunia ini sangat banyak jenis boneka, wayang tetap mempunyai kekhasan yang tidak dimiliki oleh boneka dari negara lain. Selain dari wujud atau bentuknya, kekhasan itu dapat terlihat pula dari cerita dan karakter setiap bentuk wayang.

Tak bisa dipungkiri, arus globalisasi dan modernisasi yang terlampau kencang menerpa negeri ini membuat kita melupakan budaya tradisional. Jika jaman dulu orang menonton televisi untuk menonton pertunjukan wayang kulit/golek/orang, kini ada banyak pilihan lain yang dianggap lebih menarik seperti sinetron atau sitkom. Tak heran jika semakin lama

1) Mahasiswa Teknik Sistem Komputer Undip

2) Dosen teknik Sistem Komputer Undip masyarakat semakin tidak mengenal wayang, apalagi tergerak untuk melestarikannya.

Maka di era baru ini dilibatkanlah penggunaan perangkat bergerak seperti smartphone sebagai alat yang paling efisien sebagai media pembelajaran yang interaktif. Metode pembelajaran menggunakan game merupakan metode yang sering digunakan di era modern seperti ini. Sebab tidak hanya membuat mudah untuk mengerti, namun juga membuat orang lebih mudah menghapal. Karena pada dasarnya manusia lebih mudah menghapal jika ada bentuk visualnya.

Pembelajaran tokoh wayang dapat mengadopsi dan mengadaptasi suatu media untuk mempermudah mengingat ataupun tahu tentang tokoh pewayangan dengan tujuan dari pembelajaran ini dapat tercapai dengan sebaikbaiknya. 


\subsection{Tujuan}

Tujuan dari tugas akhir ini adalah merancang dan membuat sebuah aplikasi mobile education game yang berorientasi pada pengetahuan nama tokoh wayang yang dapat berjalan pada sistem operasi iOS.

\subsection{Pembatasan Masalah}

Untuk menghindari pembahasan yang meluas maka dalam tugas akhir ini ditetapkan batasan-batasan masalah dengan hal-hal sebagai berikut:

1. Pembuatan aplikasi menggunakan GameSalad yang berintegrasi dengan Xcode yang hanya dapat berjalan di perangkat Mac OS.

2. Aplikasi dikembangkang hanya untuk perangkat iOS.

3. Game ini di batasi hanya pada permainan mencari huruf satu per satu untuk membentuk suatu nama tokoh wayang, yang dibatasi oleh waktu serta terdapat skor yang menghitung nilai yang didapat oleh pemain.

4. Aplikasi ini di mainkan untuk single player.

\section{LANDASAN TEORI}

\subsection{Wayang}

Wayang yang berasal dari kata bayang, mulai pada zaman purbakala sebagai upacara memanggil arwah dengan memasang lampu minyak kelapa dan menayangkan bayangan pada dinding atau kain putih yang dibentangkan. Wayang kemudian berkembang sejak abad ke-9 dan ke-10 sebagai media untuk pementasan lakon-lakon yang diciptakan bertemakan sastra epos (sejenis karya sastra tradisional yang menceritakan kisah kepahlawanan) Ramayana dan Mahabharata, dan kemudian sejak abad-abad pertengahan diciptakan pula lakon-lakon bertemakan agama. ${ }^{[9]}$

Secara umum macam-macam wayang yang ada di Indonesia,yaitu :

\section{Wayang Beber}

Wayang Beber adalah wayang yang dibeberkan atau dipaparkan di depan penonton. Terbuat dari kain lebar yang digambar bersambung-sambung mengenai suatu cerita. Sambil dibeberkan, dalang akan menceritakan jalan ceritanya. ${ }^{[9]}$

2. Wayang Golek

Wayang Golek dibuat dari kayu yang diukir dan disungging. Wayang Golek mengambil cerita Mahabharata dan Ramayana. Bentuknya mirip boneka (Golek dalam bahasa Jawa = boneka) yang diberi pakaian / baju, kain, dan selendang. ${ }^{[9]}$

3. Wayang Orang

Wayang Orang disebut juga dengan istilah wayang wong (jawa). Sesuai dengan nama dan sebutannya, wayang tersebut tidak lagi dipergelarkan dengan memainkan bonekaboneka wayang yang terbuat dari bahan kulit kerbau ataupun yang lain, akan tetapi menampilkan manusia-manusia sebagai pengganti boneka-boneka wayang. ${ }^{[9]}$

4. Wayang Menak

Wayang Menak diciptakan oleh Kyai Trunodipo dari Kampung Baturetno, Surakarta. Wayang ini terbuat dari kulit yang ditatah dan disungging seperti wayang Purwa. [9]

\section{Wayang Purwa}

Pertunjukan wayang yang pementasan ceritanya bersumber pada kitab Mahabrata atau Ramayana. Wayang kulit purwa terbuat dari bahan kulit kerbau, yang ditatah, diberi warna sesuai dengan kaidah pulasan wayang pedalangan, diberi tangkai dari bahan tanduk kerbau bule yang diolah sedemikian rupa dengan nama cempurit. ${ }^{[17]}$

\subsection{Flowchart}

Bagan alir (flowchart) merupakan bagan yang menggambarkan urutan dari instruksi proses maupun hubungan satu proses dengan proses yang lain dengan menggunakan simbol tertentu. Bagan alir digunakan sebagai alat bantu komunikasi dan dokumentasi.

\subsection{Teknologi iOS}

iOS adalah sistem operasi yang berjalan pada iPhone, iPod touch, dan perangkat iPad. Sistem operasi mengelola perangkat keras dan menyediakan teknologi yang dibutuhkan untuk mengimplementasikan aplikasi asli. Sistem operasi merupakan induk dari berbagai aplikasi sistem, seperti Telepon, Mail, dan Safari, yang menyediakan layanan sistem standar untuk pengguna. ${ }^{[6]}$

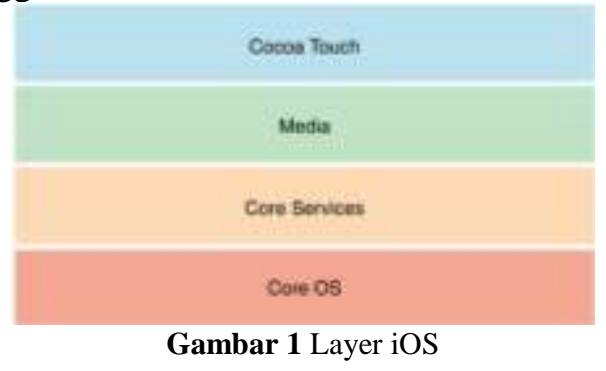




\section{4 iOS SDK}

iOS Software Development Kit (SDK) berisi alat dan interface yang diperlukan untuk mengembangkan, menginstal, menjalankan, dan menguji aplikasi asli yang muncul di layar Home perangkat iOS. Aplikasi asli yang dibangun menggunakan kerangka sistem iOS dan bahasa Objective-C dan berjalan secara langsung pada iOS. iOS SDK menyediakan sumber daya yang dibutuhkan untuk mengembangkan aplikasi asli iOS. ${ }^{[4]}$

Tabel 1 Komponen Inti iOS SDK

\begin{tabular}{|l|l|}
\hline Komponen & Deskripsi \\
\hline Xcode & $\begin{array}{l}\text { Ini merupakan Integrated } \\
\text { Development Environment } \\
\text { (IDE) yang memungkinkan } \\
\text { untuk mengelola, mengedit, dan } \\
\text { debug proyek }{ }^{[4]}\end{array}$ \\
\hline DashCode & $\begin{array}{l}\text { Hal ini memungkinkan untuk } \\
\text { mengembangkan aplikasi } \\
\text { iPhone dan iPad berbasis web, } \\
\text { dan widget Dashboard }\end{array}$ \\
\hline Simulator & $\begin{array}{l}\text { Simulator merupakan aplikasi } \\
\text { berbasis Cocoa yang } \\
\text { menyediakan perangkat lunak } \\
\text { simulator untuk mensimulasikan } \\
\text { iPhone atau iPad pada Mac OS } \\
X^{[4]} \text {. }\end{array}$ \\
\hline $\begin{array}{l}\text { Interface } \\
\text { Builder }\end{array}$ & $\begin{array}{l}\text { Ini adalah editor visual grafis } \\
\text { untuk merancang antarmuka } \\
\text { pengguna untuk aplikasi iPhone } \\
\text { dan iPad. Dalam rilis } \\
\text { sebelumnya Xcode, ini adalah } \\
\text { aplikasi mandiri yang terpisah. } \\
\text { mulai Xcode 4,hal ini telah } \\
\text { diintegrasikan sebagai bagian } \\
\text { dari pengembangan IDE }\end{array}$ \\
$\begin{array}{l}\text { Alat analisis yang membantu } \\
\text { mengoptimalkan aplikasi dan } \\
\text { memantau kebocoran memori } \\
\text { secara real-time }\end{array}$ \\
\hline Instrumen
\end{tabular}

\subsection{Xcode IDE}

Xcode adalah bagian dari apple development tools yang mendukung proyek manajemen, pengkodingan, debugging, dan juga lainnya. Xcode merupakan Integrated Development Environtmet (IDE) yang memberikan semua tools yang diinginkan untuk mengatur dan membuat aplikasi pada perangkat iOS. ${ }^{[1]}$

\subsection{GameSalad}

GameSalad menyediakan antarmuka pengguna grafis (GUI) untuk mendeskripsikan aturan dan perilaku objek permainan, disebut Aktor, tanpa pemrograman atau scripting bahasa. Perilaku adalah komponen dari aktor yang baik dapat seketika atau terus-menerus mempengaruhi aktor tergantung pada aturan yang melekat mereka. Aplikasi ini dilengkapi dengan sebuah perpustakaan perilaku (untuk gerakan, mengubah keadaan atribut, mempengaruhi tabrakan, dan lain-lain) yang dapat dimasukkan ke dalam aturan dan kelompok perilaku lain untuk menciptakan perilaku baru. ${ }^{[5]}$

\section{PERANCANGAN SISTEM \\ 3.1 Tahap Perancangan Sistem}

Sebuah sistem aplikasi akan menjadi lebih bagus apabila konsep yang disajikan juga terlihat bagus, oleh karena pentingnya sebuah perencanaan dalam proyek itu sendiri maka dalam aplikasi permainan ini akan menggunakan 4 elemen yang terdiri dari analisa kebutuhan, desain sistem, implementasi, dan pengujian program.

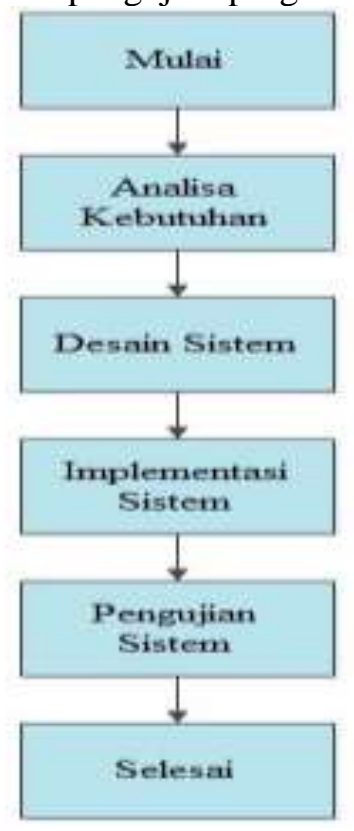

Gambar 2 Diagram Blok Tahap-Tahap Perancangan Sistem

\subsection{Analisa Kebutuhan}

Proses mengumpulkan informasi kebutuhan sistem/perangkat lunak melalui survei, mencari referensi dari berbagai sumber 
dan konsultasi dengan user system. Proses ini mendefinisikan secara rinci mengenai fungsifungsi, batasan dan tujuan dari apikasi game ini sebagai spesifikasi sistem yang akan dibuat.

\subsection{Desain Sistem}

Proses perancangan sistem ini difokuskan pada tiga atribut, yaitu diagram alir sistem, perancangan antarmuka, dan storyboard. Diagram alir sistem menggambarkan langkahlangkah dari urutan prosedur suatu program. Perancangan antarmuka merupakan bentuk tampilan dari program untuk memberi gambaran tentang aplikasi yang akan dibangun. Storyboard adalah area berseri yang digunakan sebagai alat perencanaan visual daro program permainan.

\subsection{Diagram Alir Sistem}

Diagram Alir adalah penggambaran secara grafik dari langkah-langkah dan uruturutan prosedur dari suatu program. Diagram Alir menolong analis dan programmer untuk memecahkan masalah kedalam segmensegmen yang lebih kecil dan menolong dalam menganalisis alternatif-alternatif lain dalam pengoperasian. Diagram Alir biasanya mempermudah penyelesaian suatu masalah khususnya masalah yang perlu dipelajari dan dievaluasi lebih lanjut.

1.Diagram Alir Umum

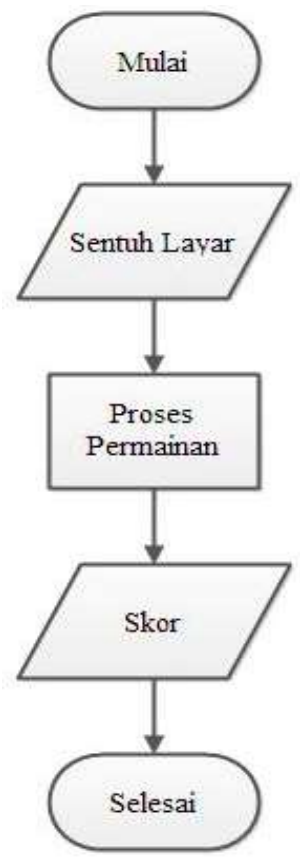

Gambar 3 Diagram Alir Umum
2.Diagram Alir Proses permainan

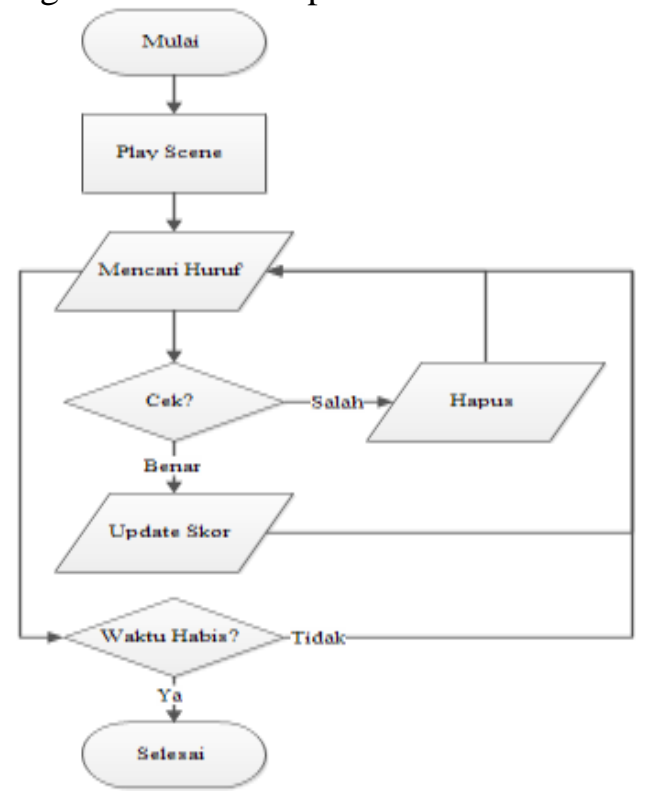

Gambar 4 Diagram Alir Proses Permainan

3.Diagram Alir Menunda Permainan (Pause)

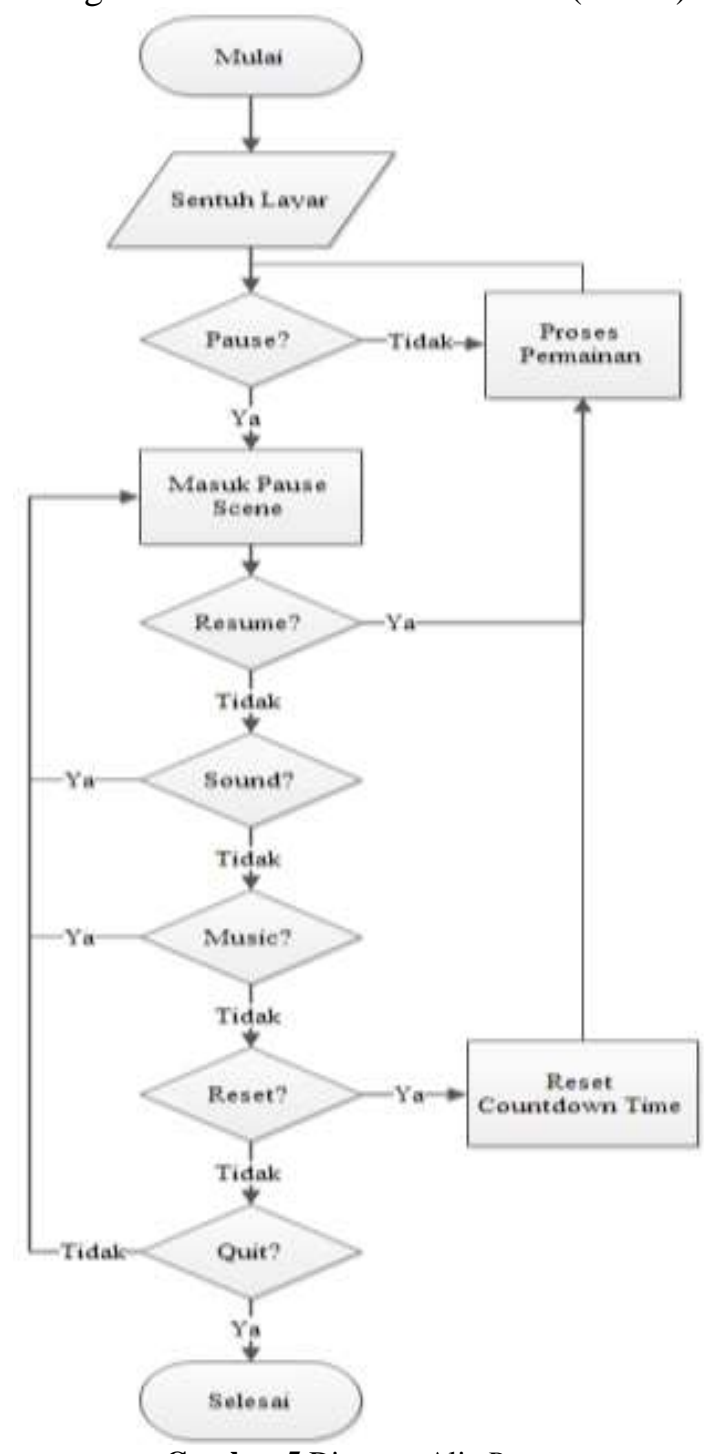

Gambar 5 Diagram Alir Pause 
4.Diagram Alir Informasi Tokoh Wayang

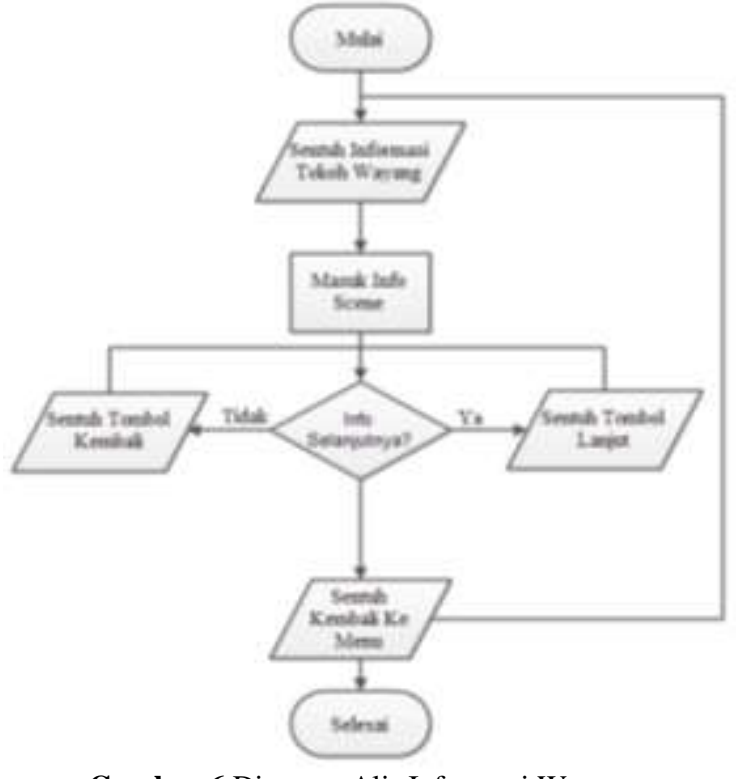

Gambar 6 Diagram Alir Informasi Wayang

\subsection{Implementasi Sistem}

Pada tahap ini, perancangan perangkat lunak direalisasikan sebagai serangkaian program atau unit program. Pada tahap ini sudah mulai mengimplementasikan desain program yang nantinya akan terbentuk fungsi. Dan fungsi inilah yang membentuk sistem. Kemudian pengujian unit melibatkan verifikasi bahwa setiap unit program telah memenuhi spesifikasinya.

\subsection{Pengujian Sistem}

Unit program atau program individual diintegrasikan menjadi sebuah kesatuan sistem dan kemudian dilakukan pengujian. Dengan kata lain, pengujian ini ditujukan untuk menguji keterhubungan dari tiap-tiap fungsi perangkat lunak untuk menjamin bahwa persyaratan sistem telah terpenuhi.

\section{IMPLEMENTASI DAN PENGUJIAN SISTEM}

\subsection{Implementasi}

Implementasi merealisasikan perancangan perangkat lunak menjadi serangkaian program atau unit program.

\subsubsection{Perancangan Adegan}

Adegan merupakan tempat dimana aktor yang terlibat akan memainkan perannya, adegan yang dibuat terdiri dari 4 adegan yakni
"Menu Scene", "Play Scene", "Pause Scene", dan "Info Scene".

\section{Menu Scene}

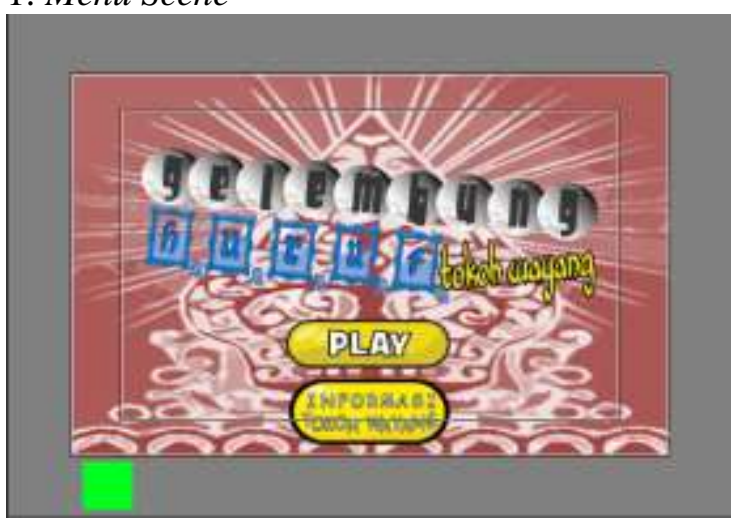

Gambar 7 Adegan Menu

Adegan dengan ukuran panjang 480 pixel dan tinggi 320 pixel, terdapat 5 aktor. Warna hijau untuk aktor Load Attributes, aktor play, aktor Info Wayang, aktor gelembunghuruf dan aktor menu yang merupakan background dari adegan.

2. Play Scene

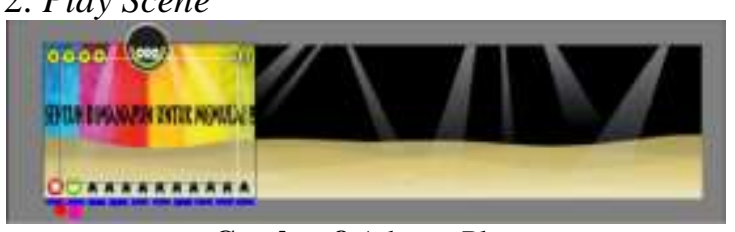

Gambar 8 Adegan Play

Adegan dengan ukuran panjang 1440 pixel dan tinggi 320 pixel. Adegan tersebut panjang dimaksutkan agar ada ruang untuk efek berjalan bagi tanah nya. Terdapat 24 macam aktor yang terlibat.

3. Pause Scene

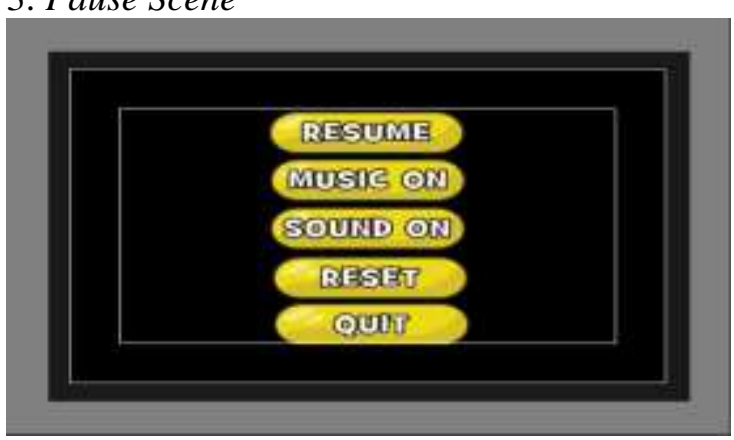

Gambar 9 Adegan Pause

Adegan dengan ukuran 480 pixel x 320 pixel. Terdapat 5 fungsi tombol yang digunakan ketika pengguna menghentikan sementara permainan, yaitu tombol "resume" untuk kembali ke permainan, "music" untuk menghidupkan/mematikan musik, "sound" untuk menghidupkan/mematikan suara, "reset" untuk mengulang permainan dan "quit" keluar dari permainan. 


\section{Info Scene}

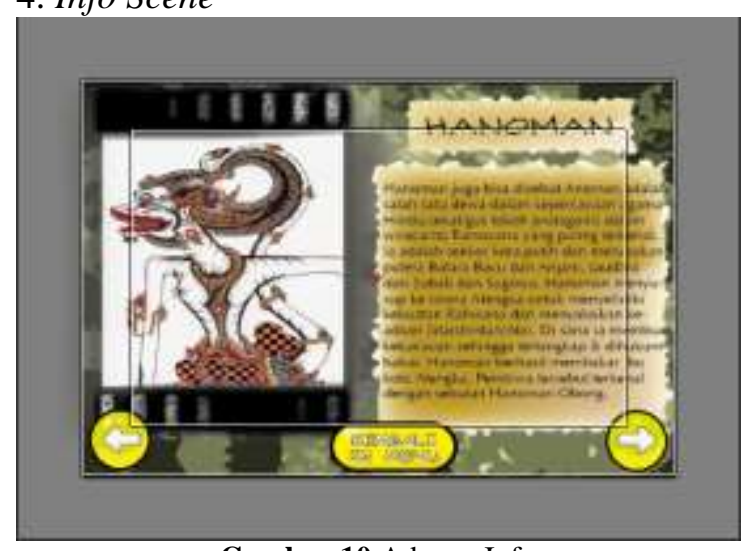

Gambar 10 Adegan Info

Adegan dengan ukuran panjang 480 pixel dan tinggi 320 pixel. Adegan ini berisi tentang informasi singkat dari tokoh wayang, beserta tiga tombol dengan fungsinya masing-masing. Tombol "Next" digambarkan seperti tanda $(\rightarrow)$, sedangkan tombol "Back" digambarkan seperti tanda $(\leftarrow)$, selain itu terdapat tombol "Kembali Ke Menu" untuk kembali ke adegan Menu.

\subsubsection{Aktor yang Terlibat}

Aktor mewakili objek terlihat dalam permainan. Aktor dapat mewakili karakter yang pemain mengendalikan atau mereka dapat menjadi obyek sekitarnya/karakter bahwa pembicaraan, bertabrakan, melompati, atau umumnya berinteraksi selama permainan berlangsung. Terdapat 40 macam aktor dalam permainan ini.

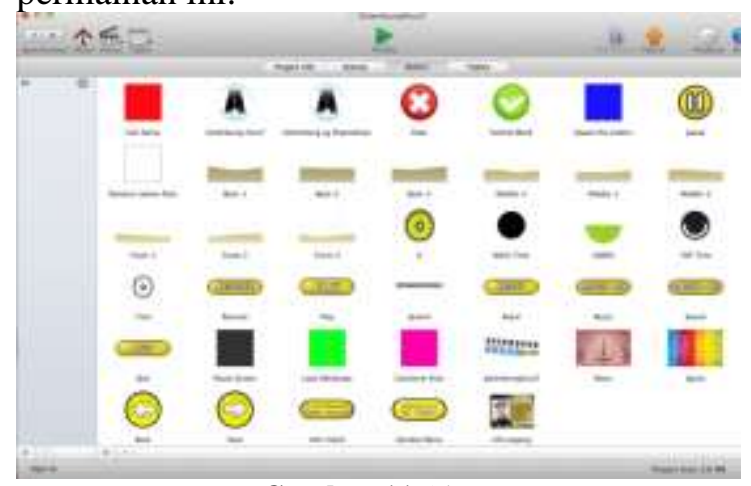

Gambar 11 Aktor

Aktor yang terlibat dalam permainan ini adalah :

Tabel 2 Tabel Aktor

\begin{tabular}{|c|l|l|}
\hline No. & \multicolumn{1}{|c|}{ Aktor } & \multicolumn{1}{c|}{ Fungsi } \\
\hline $\mathbf{1}$ & Cek Nama & $\begin{array}{l}\text { Mengecek kebenaran } \\
\text { nama yang disusun. }\end{array}$ \\
\hline $\mathbf{2}$ & $\begin{array}{l}\text { Gelembung } \\
\text { Huruf }\end{array}$ & $\begin{array}{l}\text { Huruf yang akan } \\
\text { dipilih }\end{array}$ \\
\hline $\mathbf{3}$ & $\begin{array}{l}\text { Gelembung } \\
\text { yang }\end{array}$ & $\begin{array}{l}\text { Huruf yang telah } \\
\text { dipilih }\end{array}$ \\
\hline
\end{tabular}

\begin{tabular}{|c|c|c|}
\hline & dipecahkan & \\
\hline 4 & Clear Word & Menghapus nama \\
\hline 5 & Submit Word & Menghitung skor \\
\hline 6 & $\begin{array}{l}\text { Spawn The } \\
\text { Letters }\end{array}$ & Memijah gelembung \\
\hline 7 & Pause & Masuk pause scene \\
\hline 8 & $\begin{array}{l}\text { Random Letters } \\
\text { Rule }\end{array}$ & Pengacak huruf \\
\hline 9 & Back-1 & Efek tanah berjalan \\
\hline 10 & Back-2 & Efek tanah berjalan \\
\hline 11 & Back-3 & Efek tanah berjalan \\
\hline 12 & Middle-1 & Efek tanah berjalan \\
\hline 13 & Middle-2 & Efek tanah berjalan \\
\hline 14 & Middle-3 & Efek tanah berjalan \\
\hline 15 & Front-1 & Efek tanah berjalan \\
\hline 16 & Front-2 & Efek tanah berjalan \\
\hline 17 & Front-3 & Efek tanah berjalan \\
\hline 18 & 0 & Skor \\
\hline 19 & Back Time & Backround waktu \\
\hline 20 & GREEN & Penghitung mundur \\
\hline 21 & TOP Time & Elemen waktu \\
\hline 22 & Time & Waktu \\
\hline 23 & Resume & $\begin{array}{l}\text { Kembali ke } \\
\text { permainan }\end{array}$ \\
\hline 24 & Play & Masuk play scene \\
\hline 25 & Sentuh & Mulai permainan \\
\hline 26 & Reset & $\begin{array}{l}\text { Mengulang } \\
\text { permainan }\end{array}$ \\
\hline 27 & Music & On/off musik \\
\hline 28 & Sound & On/off suara \\
\hline 29 & Quit & Keluar permainan \\
\hline 30 & Pause Screen & Backround pause \\
\hline 31 & Load Attributes & Memuat atribut \\
\hline 32 & Gameover Rule & $\begin{array}{l}\text { Pengaturan ber- } \\
\text { akhirnya permainan }\end{array}$ \\
\hline 33 & gelembunghuruf & Judul aplikasi \\
\hline 34 & Menu & $\begin{array}{l}\text { Backround menu } \\
\text { scene }\end{array}$ \\
\hline 35 & bgron & $\begin{array}{l}\text { Backround play } \\
\text { scene }\end{array}$ \\
\hline 36 & Back & $\begin{array}{l}\text { Kembali ke info } \\
\text { wayang sebelumnya }\end{array}$ \\
\hline 37 & Next & $\begin{array}{l}\text { Lanjut ke info } \\
\text { wayang selanjutnya }\end{array}$ \\
\hline 38 & Info Tokoh & $\begin{array}{l}\text { Navigasi ke info } \\
\text { scene }\end{array}$ \\
\hline 39 & Kembali Menu & $\begin{array}{l}\text { Navigasi ke menu } \\
\text { scene }\end{array}$ \\
\hline 40 & info wayang & $\begin{array}{l}\text { Tempat info singkat } \\
\text { tokoh wayang }\end{array}$ \\
\hline
\end{tabular}




\subsection{Pengujian Permainan}

Pengujian permainan "Gelembung Huruf (Tokoh Wayang)" dilakukan dengan menggunakan metode black-box, pengujian ini menekankan pada fungsionalitas dari permainan. Tahap ini berisi serangkaian pengujian fungsi dan tombol pada permainan. Tingkat keberhasilan pengujian, diukur dari terpenuhinya spesifikasi kebutuhan dan skenario permainan. Pengujian permainan dijalankan pada perangkat bersistem operasi iOS maupun menggunakan emulator. Cara pengujiannya hanya dilakukan dengan mengeksekusi Proyek, kemudian diamati apakah hasilnya sesuai dengan spesifikasi kebutuhan.

Tabel 3 Tabel Pengujian Fungsi pada Permainan

\begin{tabular}{|c|l|c|}
\hline No. & \multicolumn{1}{|c|}{ Fungsi } & Hasil Uji \\
\hline 1. & $\begin{array}{l}\text { Menampilkan halaman } \\
\text { awal permainan }\end{array}$ & Berhasil \\
\hline 2. & Pemilihan menu play & Berhasil \\
\hline 3. & Pemilihan menu Info & Berhasil \\
\hline $\mathbf{4 .}$ & $\begin{array}{l}\text { Menampilkan Informasi } \\
\text { Tokoh }\end{array}$ & Berhasil \\
\hline 5. & $\begin{array}{l}\text { Pemilihan } \\
\text { Everywhere to Start! }\end{array}$ & Berhasil \\
\hline 6. & $\begin{array}{l}\text { Menampilkan skor } \\
\text { tertinggi }\end{array}$ & Berhasil \\
\hline 7. & Memainkan permainan & Berhasil \\
\hline 8. & $\begin{array}{l}\text { Memperbarui skor } \\
\text { realtime }\end{array}$ & Berhasil \\
\hline 9. & Countdown timer & Berhasil \\
\hline $\mathbf{1 0 .}$ & $\begin{array}{l}\text { Menampilkan adegan } \\
\text { pause }\end{array}$ & Berhasil \\
\hline 11. & Menu resume & Berhasil \\
\hline $\mathbf{1 2 .}$ & Menu sound & Berhasil \\
\hline 13. & Menu music & Berhasil \\
\hline 14. & Menu reset & Berhasil \\
\hline $\mathbf{1 5}$. & Menu quit & Berhasil \\
\hline
\end{tabular}

Tabel 4 Tabel Pengujian Tombol pada Permainan

\begin{tabular}{|c|l|l|c|}
\hline No. & $\begin{array}{l}\text { Parameter } \\
\text { Pengujian }\end{array}$ & \multicolumn{1}{|c|}{ Keterangan } & \multicolumn{1}{|c|}{$\begin{array}{c}\text { Uasil } \\
\text { Uji }\end{array}$} \\
\hline 1. & $\begin{array}{l}\text { Tombol } \\
\text { Kembali }\end{array}$ & $\begin{array}{l}\text { Ketika tombol } \\
\text { ditekan, maka } \\
\text { pengguna akan } \\
\text { menampilkan } \\
\text { informasi dari } \\
\text { tokoh wayang } \\
\text { sebelumnya. }\end{array}$ & \\
\hline
\end{tabular}

\begin{tabular}{|c|c|c|c|}
\hline 2. & $\begin{array}{l}\text { Tombol } \\
\text { Lanjut }\end{array}$ & $\begin{array}{l}\text { Ketika tombol } \\
\text { ditekan, maka } \\
\text { pengguna akan } \\
\text { menampilkan } \\
\text { informasi dari } \\
\text { tokoh wayang } \\
\text { selanjutnya. }\end{array}$ & Benar \\
\hline 3. & $\begin{array}{l}\text { Tombol } \\
\text { Resume }\end{array}$ & $\begin{array}{l}\text { Ketika tombol } \\
\text { ditekan, maka } \\
\text { pengguna bisa } \\
\text { melanjutkan } \\
\text { permainan } \\
\text { semula tanpa } \\
\text { memulai dari } \\
\text { awal }\end{array}$ & Benar \\
\hline 4. & $\begin{array}{l}\text { Tombol } \\
\text { Music }\end{array}$ & $\begin{array}{l}\text { Ketika tombol } \\
\text { ditekan, maka } \\
\text { musik saat } \\
\text { permainan } \\
\text { berlangsung } \\
\text { dalam keadaan } \\
\text { on (hidup) atau } \\
\text { off (mati). }\end{array}$ & Benar \\
\hline 5. & $\begin{array}{l}\text { Tombol } \\
\text { Sound }\end{array}$ & $\begin{array}{l}\text { Ketika tombol } \\
\text { ditekan, maka } \\
\text { suara saat } \\
\text { permainan } \\
\text { berlangsung } \\
\text { dalam keadaan } \\
\text { on (hidup) atau } \\
\text { off (mati). }\end{array}$ & Benar \\
\hline 6. & $\begin{array}{l}\text { Tombol } \\
\text { Reset }\end{array}$ & $\begin{array}{l}\text { Ketika tombol } \\
\text { ditekan, maka } \\
\text { permainan akan } \\
\text { diulang kembali } \\
\text { dari awal. Baik } \\
\text { itu skor maupun } \\
\text { waktunya, skor } \\
\text { sebelumnya } \\
\text { tidak disimpan. }\end{array}$ & Benar \\
\hline 7. & $\begin{array}{l}\text { Tombol } \\
\text { Clear } \\
\text { Word }\end{array}$ & $\begin{array}{lr}\text { Ketika } & \text { tombol } \\
\text { ditekan, maka } \\
\text { akan menghapus } \\
\text { nama atau huruf } \\
\text { yang r telah } \\
\text { disusun }\end{array}$ & Benar \\
\hline 8. & $\begin{array}{l}\text { Tombol } \\
\text { Submit } \\
\text { Word }\end{array}$ & $\begin{array}{l}\text { Ketika tombol } \\
\text { ditekan, maka } \\
\text { akan skor akan } \\
\text { bertambah } \\
\text { sesuai dengan } \\
\text { banyaknya huruf }\end{array}$ & Benar \\
\hline
\end{tabular}




\begin{tabular}{|c|c|c|c|}
\hline & & yang disusun. & \\
\hline 9. & $\begin{array}{l}\text { Tombol } \\
\text { Play }\end{array}$ & $\begin{array}{l}\text { Ketika tombol } \\
\text { ditekan, maka } \\
\text { pengguna di } \\
\text { navigasikan } \\
\text { langsung } \\
\text { menuju adegan } \\
\text { selanjutnya } \\
\text { yaitu dapat } \\
\text { memulai } \\
\text { permainan. }\end{array}$ & Benar \\
\hline 10. & $\begin{array}{l}\text { Tombol } \\
\text { Informasi } \\
\text { Tokoh } \\
\text { Wayang }\end{array}$ & $\begin{array}{l}\text { Ketika tombol } \\
\text { ditekan, maka } \\
\text { pengguna di } \\
\text { navigasikan } \\
\text { langsung } \\
\text { menuju adegan } \\
\text { Info yaitu } \\
\text { adegan yang } \\
\text { berisi tentang } \\
\text { informasi } \\
\text { singkat dari para } \\
\text { tokoh wayang. }\end{array}$ & Benar \\
\hline 11. & $\begin{array}{l}\text { Tombol } \\
\text { Kembali } \\
\text { Ke Menu }\end{array}$ & $\begin{array}{l}\text { Ketika tombol } \\
\text { ditekan, maka } \\
\text { pengguna di } \\
\text { navigasikan } \\
\text { langsung } \\
\text { menuju adegan } \\
\text { Menu. }\end{array}$ & Benar \\
\hline 12. & $\begin{array}{l}\text { Tombol } \\
\text { Pause }\end{array}$ & $\begin{array}{l}\text { Ketika tombol } \\
\text { ditekan, maka } \\
\text { permainan akan } \\
\text { berhenti, } \\
\text { pengguna akan } \\
\text { di navigasikan } \\
\text { ke adegan } \\
\text { pause. }\end{array}$ & Benar \\
\hline 13. & $\begin{array}{l}\text { Tombol } \\
\text { Quit }\end{array}$ & $\begin{array}{l}\text { Ketika tombol } \\
\text { ditekan, maka } \\
\text { pengguna akan } \\
\text { keluar dari } \\
\text { permainan dan } \\
\text { di navigasikan } \\
\text { langsung } \\
\text { menuju adegan } \\
\text { Menu. }\end{array}$ & Benar \\
\hline
\end{tabular}

\subsection{Pembahasan}

Secara fungsional, permainan ini sudah dapat menghasilkan keluaran yang diharapkan. Berdasarkan pengujian terdapat kelebihan dan kekurangan dari permainan ini.

Kelebihan permainan ini yaitu sebagai berikut:
1. Permainan dapat dijalankan pada perangkat bergerak dengan sistem operasi iOS.

2. Huruf yang muncul selalu dalam keadaan acak sehingga pengguna harus lebih teliti dalam mencari huruf yang dibutuhkan dalam menyusun nama tokoh wayang yang diinginkan, hal ini dapat meningkatkan fokus dari pengguna.

3. Permainan ini dapat menambah pengetahuan berupa informasi dari tokohtokoh wayang.

4. Permainan mudah dipahami dan dijalankan, sehingga menarik perhatian bagi pengguna yang inggin mencoba untuk memainkan permainan ini.

5. Ukuran file dari permainan ini tidak terlalu besar, yaitu $8 \mathrm{MB}$, sehingga tidak menggunakan ruang yang besar pada penyimpanan di perangkat bergerak.

6. Permainan ini memiliki fitur High Score yang di tampil kan pada awal permainan, hal ini dapat merangsang minat pengguna untuk mengalahkan skor tertinggi berikutnya.

7. Permainan ini memiliki nilai budaya karena memfokuskan pada nama tokoh wayang.

Adapun kekurangan dari permainan ini yaitu sebagai berikut :

1. Permainan terlalu fokus pada nama tokoh wayang, sehingga orang yang tidak tertarik dalam hal wayang tidak punya opsi pilihan lainnya.

2. Permainan terlalu simpel, tidak ada level dari permainan tersebut.

3. Untuk dapat memainkan permainan ini, harus mempunyai perangkat yang berbasis sistem operasi iOS terlebih dahulu.

\section{KESIMPULAN DAN SARAN}

\subsection{Kesimpulan}

Dari hasil pengujian dan analisis permainan edukasi "Gelembung Huruf (Tokoh Wayang)" dapat disimpulkan hal-hal sebagai berikut.

1. Permainan dapat dijalankan dengan baik pada perangkat bergerak dengan sistem operasi iOS.

2. Tombol-tombol dan fungsi-fungsi yang terdapat pada permainan dapat berfungsi dengan baik dan sesuai dengan fungsionalitasnya masing-masing.

3. Permainan ini dapat melatih fokus dan ketelitian dari pengguna karena huruf yang 
ditampilkan secara realtime dilakukan secara acak, sehingga pengguna perlu mencari huruf yang sesuai dengan apa yang disusun.

4. Permainan ini dapat menambah pengetahuan berupa informasi dari tokoh-tokoh wayang.

\subsection{Saran}

Permainan yang sudah dibuat sudah berjalan dengan baik sesuai dengan tujuan awal dari penelitian ini. Adapun saran untuk pengembangan pada permainan "Gelembung Huruf (Tokoh Wayang)" ini yaitu :

1. Permainan ini dibutuhkan penambahan level permainan, seperti tingkat kesulitan, dalam hal ini variasi waktu.

2. Sebaiknya fokus dari permainan ini dibuat lebih umum, tidak hanya pada tokoh wayang. Misalnya seperti, nama pahlawan, nama kota, nama negara, nama hewan, dan lain-lain. Sehingga pengguna tidak cepat bosan dan dapat memilih tantangan apa yang disukai.

\section{DAFTAR PUSTAKA}

[1] Alessi, Patrick. Beginning iOS Game Development. Indianapolis: John Wiley \& Sons, Inc., 2012.

[2] Ardisoma, S.. Wayang Purwa. Jakarta: Pluz+, 2010.

[3] Brant, Troy. iPad and iPhone App Development. Indianapolis: Penguin Group (USA) Inc., 2010.

[4] Daniel, Steven F. Xcode 4 iOS Development Beginner's Guide. Birmingham: Packt Publishing Ltd., 2011.

[5] DeQuadros, Miquel. GameSalad Beginner's Guide. Birmingham : Packt Publishing Ltd., 2012.

[6] Goldstein, Neal. Paris ButtfieldAddison. Jon Manning. iPhone \& iPad Game Development For Dummies. Indianapolis : Wiley Publishing,Inc., 2011.

[7] Goldstein, Neal. Tony Bove. iPad Application Development For Dummies, 2nd Edition. Indianapolis : Wiley Publishing,Inc., 2011.

[8] Guerineau, David. Learn GameSalad for iOS: Game Development for
iPhone, iPad, and HTML5. New York : Apress., 2012.

[9] Haryanto, S. Pratiwimba Adhiluhung: Sejarah dan Perkembangan Wayang. Jakarta: Djambatan, 1988.

[10] Jendra, Wayan. Dasa Pandawa. Jakarta: Dep P Proyek Penerbitan buku Sastra Indonesia dan Daerah, 1980.

[11] Kartapraja, R. Ng. \& Sudibjo Z.H.. Bratayuda. Jakarta: Dep P Proyek Penerbitan buku Sastra Indonesia dan Daerah, 1980.

[12] Kosasih, R.A.. Ramayana . Jakarta: Pluz+, 2009.

[13] Nutting, Jack. Dave Wooldridge. David Mark. Beginning iPad Development for iPhone Developers: Mastering the iPad SDK. New York: Apress., 2010.

[14] Pressman, S.R. Software Engineering a Practitioner's Approach, USA: Mc Grawhill.Inc, 1997.

[15] Ray, John. Sams Teach Yourself iPhone Application Development in 24 Hours Second Edition. New Jersey: Pearson Education, Inc., 2011.

[16] Simarmata, Janner, Rekayasa Perangkat Lunak, Andi Publisher, Jakarta, 2007.

[17] Sudjarwo, Heru S., Sumari, Undung Wiyono. Rupa \& Karakter Wayang Purwa. Jakarta: Kakilangit Kencana, 2010.

[18] Yasin, Verdi, Rekayasa Perangkat Lunak Berorientasi Objek, Mitra Wacana Media, Jakarta, 2012. 


\section{BIODATA}

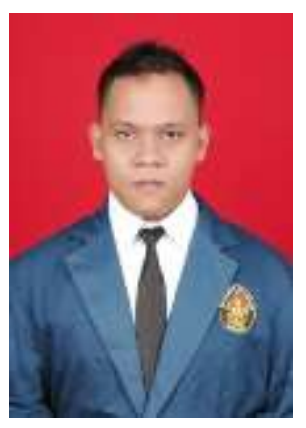

Adhitama Ksatriya Nugraha, lahir di Grobogan 30 November 1989. Pendidikan yang telah ditempuh yaitu TK Tunas Simpang, SD Negeri 12, SMP Negeri 2, SMA Negeri 1 yang semuanya berada di kota Purwodadi. Sekarang sedang menyelesaikan pendidikan Strata Satu di Program Studi Sistem Komputer, Universitas Diponegoro, Semarang, Indonesia Angkatan Tahun 2008.

Mengetahui/Mengesahkan

Dosen Pembimbing I

\section{Ir. Kodrat Iman Satoto, M.T.}

NIP 196310281993031002

Mengetahui/Mengesahkan

Dosen Pembimbing II

Rinta Kridalukmana, S.Kom., M.T.

NIP 197706152008011011 